DOI 10.31392/NPU-nc.series15.2021.6(137).04
UDC 796.01:373.04

\author{
Shuba Liudmyla \\ Assistant Professor, PhD in Pedagogy, \\ Associate Professor of the Physical Culture and Sport Management Department "Zaporizhzhia Polytechnic" \\ National University, Zaporizhzhia \\ Shuba Victoria \\ PhD in Pedagogy, Associate Professor of the Pedagogy and Psychology Department \\ Prydniprovska State Academy of Physical Culture and Sports
}

\title{
THE METHOD FOR STRENGTH ABILITIES RAISING OF 12-13 YEAR OLD BOYS
}

In these modern days teenagers are often interested in body-building. These hobbies can be used to generate interest in exercising in general and promote the development of muscle strength in particular. Middle school age is coincident with the end of the organism formation. At this time, the motor individuality of adult is finally formed. The deterioration of motor coordination with the intensive development of speed and speed-strength abilities is characterized for teenagers. There is a complex process of character and interests formation in life. The purpose of the article is - to demonstrate the influence of advanced method aimed at increasing the level of strength abilities for 12-13 year old boys. The research was performed from September 2020 to April 2021, experimentation facility was Gymnasium №107, Zaporizhia. It was attended by 57 boys aged 12-13 who were divided into experimental $(n=29)$ and control $(n=28)$ groups, all boys were classified in the main medical group. The advanced method has a clear applied orientation and is implemented mainly through the using of practical methods and forms, organization of lessons and aimed at implementing the variative principle. It includes: curriculum planning according to material and technical resources, staffing; age-sex characteristics of pupils, interests, provides succession and continuity between lessons; has a developmental character, applied orientation of the educational process and is aimed at forming a harmonious person. Important in organization of physical training lessons is the regular string of exercises focused on developing various strengths forms and their combination with other exercises. The obtained results showed that the indexes of strength training for 12-13 year old boys in the experimental group improve by $12.28 \%$, and in the control group only by $6.42 \%$. The positive influence of the elaborated method has been stated. The efficiency of the given method has been proved by the obtained data.

Key words: pupils, method, strength abilities, improvement, result.

Шуба Л.В. Шуба В.В. Методика підвищення рівня силових здібностей хлопців 12-13 років. Підлітки часто захоплюються атлетичною гімнастикою. Це можна використати для формування інтересу до занять 3 фізичної культури та сприяти вихованню сили м'язів. Мета статmі - продемонструвати вплив удосконаленої методики спрямованої на підвищення рівня силової підготовленості хлопців 12-13 років. Дослідження проводилось з вересня 2020 по квітень 2021, на базі Запорізької Гімназіі №107. Було залучено 57 хлопців (основної медичної групи), які були поділені на експериментальну $(n=29)$ та контрольну $(n=28)$ груп. Удосконалена методика має чітко виражену прикладну спрямованість і реалізується переважно шляхом застосування практичних методів і фрорм організації занять. Включає: планування навчального процесу відповідно до матеріально-технічного та кадрового забезпечення; віково-статевих особливостей учнів, інтересів, забезпечення безперервність і наступність між заняттями; має розвивальний характер та прикладну спрямованість навчального процесу. Важливим в організації уроків фрізичної культури $є$ правильна послідовність вправ, спрямованих на розвиток різних силових здібностей. Отримані показники силової підготовленості у експериментальній групі зросли на 12,28\%, а у контрольній групі лише на 6,42\%.

Ключові слова: учні, методика, силові здібності, покращення, результат.

Articulation of issue. In these modern days, in the conditions of constant decrease in the level of motor activity in adolescents during the school day, great importance is attached to the issue aimed at using effective methods of physical training lessons. In our opinion, the using strength exercises can be an effective way to improve the development level of physical abilities for pupils and increase motivation to exercise. The problem of basic strength training for pupils is currently of particular interest due to the pronounced changes in social, environmental and economic conditions of society [1, 3, 8, 9].

Literature route. According to K. S. Dahab, T. M. Mc Cambridge [2]; W. Jagiełło, R.M. Kalina, W. Tkaczuk [6]; R. M. Malina [11]; L. Sewall, L.J. Micheli [13]; V. Veremeenko, O. Khudolii, O. Ivashchenko [16] - analysis of the main methodical recommendations with wide using of various methods of strength training, promotes great scientific and practical interest. Because the level of strength training not only reflects the motor functions development in general, but is one of the main and most visible signs for physical improvement.

These aspects set a difficult task for the physical education teacher to plan the studying process to it provide the necessary level of strength training for pupils. The difficulty lies primarily in determining the optimal ratio of lesson time between the strength abilities development and the formation of physical qualities. Besides, it is necessary to consider that in most cases studying of a new program material should be preceded by the general force preparation which provides more effective, and the main correct formation of physical qualities $[4,5,7,10,17]$.

One of the most important tasks which every physical education teacher is facing the modelisation of effective tools and methods for the strength development. It becomes especially relevant in working with teenagers [1, 6, 12, 14].

$\mathrm{O}$. Khudolii and D.Kirk considered that the teenagers must understand the culture of attitude to their health and level of physical fitness as it is an integral part of the general culture, which largely determines social and moral status [7,8]. 
Considering the pedagogical and physiological features in the development of strength abilities and on this basis, it is possible to plan more objectively strength training and take into consideration age peculiarities in physical training lessons.

The purpose of the article is to demonstrate the influence of advanced method aimed at increasing the level of strength abilities for 12-13 year old boys.

Presentation of the main study material. The research was performed from September 2020 to April 2021, experimentation facility was Gymnasium №107, Zaporizhia. It was attended by 57 boys aged 12-13 who were divided into experimental $(n=29)$ and control $(n=28)$ groups, all boys were classified in the main medical group.

The modern pace of life requires pupils to take care of their physical development at a young age, have knowledge in the hygiene and health intervention, lead a healthy lifestyle, do physical exercises on their own.

The theory and methods of school physical education is being developed in recent years at a significant pace, replenished with new data and become increasingly practical $[5,7,9,11]$. However, the goal of physical culture can be achieved only with proper management of the pedagogical process, which will take into account the development of strength abilities and motivation to study $[2,6,12,17]$.

The improved method has a clear applied orientation and is implemented mainly through the using practical methods and forms, organization of lessons and aimed at implementing the variative principle. It includes: curriculum planning according to material and technical resources, staffing; age-sex characteristics of pupils, interests, provides succession and continuity between lessons; has a developmental character, applied orientation of the educational process and is aimed at forming a harmonious person.

We consider that the following exercises are the most effective for the development of muscle mass: exercises with using things of different weights, exercises with overcoming the resistance of elastic things. Exercises with a partner and exercises in overcoming the resistance of own body with additional burdens are also quite effective.

It is expedient to carry out the specified exercises, using interval and comprehensive methods, adhering to a number of methodological recommendations, in particular:

1. The value of external resistance is suit according to individual characteristics and give opportunity for a pupil to overcome it for $20-55$ seconds.

2. Completion rate of dynamic exercises. The greatest training effect is become apparent when performing the overcoming phase of movement in 1.0-1.5 seconds, and gradual - in 2-3 seconds.

3. Set per exercise. Amateur usually perform an exercise 2-3 sets, and able-bodied pupil - up to 5-6 sets per muscle group.

4. The required number of sets is done for one muscle group, than starts training of another muscle group. At the same time, first perform exercises for more massive muscle groups, and then - for smaller.

5. An extreme rest interval is used between sets. It is advisable to use a full rest interval between series of exercises for different muscle groups.

6. The complexion of rest between sets is active, and between series of exercises for different muscle groups - combined.

7. It is advisable to work not more than one third of the skeletal muscles in one lesson, for example only the muscles of the arms and rotator cuff or only the trunk muscles.

8. In a system of cognate lessons, the task of developing muscle strength can be solved by alternately developing different muscle groups. For example: 1st lesson - leg and pelvic muscles; 2nd lesson - the trunk muscles; lesson 3rd - the muscles of the arms and rotator cuff.

On the following lessons, this cycle is repeated many times over 4-6 weeks without change. This construction of classes gives a fairly high training effect.

With the object of maintain the achieved training effect, you should continue to perform strength exercises for those muscle groups that are already sufficiently developed. To do this requires to make use of power load making 30-40\% of loadings of a cycle. As the muscular system improves, the training load should adequately increase. One must bear in mind the fact that the size of load should be such that the pupil could overcome it from 5-6 to 10-12 times in one set.

It is important in organization of physical training lessons to do the regular string of exercises focused on developing various strengths forms and their combination with other exercises. In one lesson, strength exercises should be distributed in the following sequence: exercises for explosive strength, then - for force maxima and than for strength endurance.

Strength exercises are performed in lesson after speed exercises, before the development of endurance. The duration of strength training in physical education lessons may reach up to 10-12 minutes, but it also depends on the topics that are planned during the semester.

At the beginning and at the end of the research, all pupils met the control standards $[15,18]$, which allowed determining the level of physical qualities development and level of physical preparedness:

1. Do sit-ups for 1 minute (number of times) - testing abdominal muscle strength abilities.

2. Floor dips (number of times) - testing strength abilities of the muscles of the hands.

3. Standing long jumps $(\mathrm{cm})$ - develops such qualities as strength, speed, learn to navigate in space, concentrate efforts (testing of speed-strength abilities). endurance).

4. Abdominal raise (number of times) - testing of the maximum dynamic strength of the abdominal muscles (strength

5. Rope-climb (m) - testing of the arms and shoulders strength.

6. Upward jump off both feet $(\mathrm{cm})$ - testing of speed-strength abilities.

7. Hoop the medicine ball $(\mathrm{cm})$ - testing of speed-strength abilities.

The competitor gets behind the line to the wall, bends his hands in his elbows and squeezes the ball into his chest. After that, he pushes it forward as far as possible. The distance of the flying ball is measured up to $10 \mathrm{~cm}[15,18]$. 
One of the most promising areas for optimizing physical education is the rational use of effective tools, methods and technologies to improve motor abilities in order to increase physical development, physical fitness, strengthening health.

The obtained data show that the groups are homogeneous in all indicators of motor abilities testing: "Do sit-ups for 1 minute" (V - 9,13\% CG, V- 9,07\% EG), "Floor dips" (V - 7,39\% CG, V - 7,26\% EG), "Standing long jumps" (V - 8,12\% CG, V $8,38 \% \mathrm{EG})$, "Upward jump off both feet" (V-8,24\% CG, $V-7,96 \% \mathrm{EG})$.

For the tests: "Abdominal raise" (V- 12,09\% CG, V- 12,56\% EG), "Rope-climb" (V - 14,12\% CG, V - 14,11\% EG), "Hoop the medicine ball" (V-13,79\% CG, V - 13,51\% EG) - the fluctuations of the results were average.

Table 1 presents level of the physical fitness indicators before and after the implementation of experimental method.

Table 1

Statistical indicators of the motor abilities development before and after the research

\begin{tabular}{|c|c|c|c|c|c|c|}
\hline \multirow{3}{*}{ Tests } & \multicolumn{2}{|c|}{ Before research } & \multirow{3}{*}{$P$} & \multicolumn{2}{|c|}{ After research } & \multirow{3}{*}{$P$} \\
\hline & $E G(n=29)$ & $C G(n=28)$ & & $E G(n=29)$ & $C G(n=28)$ & \\
\hline & $X \pm S$ & $X \pm S$ & & $X \pm S$ & $\mathrm{X} \pm \mathrm{S}$ & \\
\hline $\begin{array}{l}\text { Do sit-ups for } 1 \text { minute, } \\
\text { number of times }\end{array}$ & $24,1 \pm 0,31$ & $24,2 \pm 0,32$ & $>0,05$ & $35,4 \pm 0,36$ & $28,3 \pm 5,36$ & $<0,05$ \\
\hline Floor dips, number of times & $18,0 \pm 0,17$ & $17,7 \pm 0,16$ & $>0,05$ & $24,3 \pm 0,37$ & $20,6 \pm 0,21$ & $<0,01$ \\
\hline Standing long jumps, cm & $141,2 \pm 0,88$ & $140,4 \pm 0,91$ & $>0,05$ & $157,7 \pm 0,84$ & $149,2 \pm 0,67$ & $<0,05$ \\
\hline $\begin{array}{l}\text { Abdominal raise, number of } \\
\text { times }\end{array}$ & $7,0 \pm 0,02$ & $7,0 \pm 0,02$ & $>0,05$ & $13,0 \pm 0,03$ & $9,0 \pm 0,07$ & $<0,01$ \\
\hline Rope-climb, m & $2,0 \pm 0,01$ & $2,0 \pm 0,01$ & $>0,05$ & $4,0 \pm 0,12$ & $2,8 \pm 0,13$ & $<0,01$ \\
\hline Upward jump off both feet, $\mathrm{cm}$ & $22,1 \pm 0,32$ & $22,4 \pm 0,41$ & $>0,05$ & $30,1 \pm 1,11$ & $26,2 \pm 1,08$ & $<0,05$ \\
\hline Hoop the medicine ball, $\mathrm{cm}$ & $47,0 \pm 4,16$ & $46,5 \pm 4,34$ & $>0,05$ & $54,9 \pm 3,16$ & $48,4 \pm 2,71$ & $<0,01$ \\
\hline
\end{tabular}

Analyzing the obtained data, we state that the use of advanced method has provided an increase in the level of physical abilities development in almost all indexes: "Do sit-ups for 1 minute" (number of times) - testing abdominal muscle strength abilities: CG improved by 5\%, EG - 11\%; "Floor dips" (number of times) - testing strength abilities of the muscles of the hands: CG improved by $7 \%$, EG - $15 \%$.

"Standing long jumps" (cm) - testing of speed-strength abilities, in this test there was the largest increase in performance in both groups: CG improved by 12\%, EG - 19\%. "Abdominal raise" (number of times) - testing of the maximum dynamic strength of the abdominal muscles (strength endurance): CG improved by $3 \%, E G-7 \%$.

"Rope-climb" (m) - testing of the arms and shoulders strength, in this test there was the lowest increase in both groups: CG improved by $4 \%, E G-9 \%$. This is because the chosen test is a bit difficult for this age group.

"Upward jump off both feet" (cm) - testing of speed-strength abilities: CG improved by $8 \%$, EG - 14\%; "Hoop the medicine ball" (cm) - testing of speed-strength abilities: CG improved by $6 \%, E G-11 \%$.

Based on scientific research was demonstrated that the physical abilities development with using advanced experimental method has a positive effect and a right to exist.

\section{Conclusions.}

The basis of the methodological approach to the strength-building activities for teenagers is a comprehensive education of physical qualities. This recommendation arises from the concept that at this age positive transfer of physical qualities is vividly show.

When choosing methods of strength training for teenagers in the physical education preference should be given to interval and comprehensive methods, which are accompanied by weight gain or amount of re-doing exercise.

Analyzing the obtained results, we note that the indexes of strength training for 12-13 year old boys in the experimental group improved by $12.28 \%$, and in the control group only by $6.42 \%$.

In such a way, harmonious formation and development of strength take place under the condition of a qualitative methodological recommendations in the complex training of all muscle groups. The obtained results testify to the effectiveness of the improved method.

\section{References}

1. Barbieri, D. L. Zaccagni, R. (2013) Training before and during Adolescence, Coll. Antropol, 37 Suppl, 2, 219-225.

2. Dahab, K. S., McCambridge, T. M. (2009). Strength Training in Children and Adolescents: Raising the Bar for Young Athletes? Sports Health, 1(3), 223-226. doi: 10.1177/1941738109334215

3. Dias, A. F., Lemes, V. B., Brand, C. (2017) Association between school structure and physical activity in physical education class and school recess. The Revista Brasileira de Cineantropometria e Desempenho Humano, 19(2), 164-17

4. Fransen, J., Pion, J., Vandendriessche, J., Vandorpe, B., Vaeyens, R., Lenoir, R., Philippaerts, R. M. (2012). Differences in physical fitness and gross motor coordination in boys aged 6-12 years specializing in one versus sampling more than one sport. Journal of Sports Sciences, 30, 379-386.

5. Hollis, J. L., Sutherland, R., Williams, A. J. (2017). A systematic review and meta-analysis of moderate-to-vigorous physical activity levels in secondary school physical education lessons. International Journal of Behavioral Nutrition \& Physical Activity, 14(2), 52-78

6. Jagiełło, W., Kalina, R.M., Tkaczuk. W. (2004). Development of strength abilities in children and youths. Biology of Sport, 21 (4), 351-368.

Ukrainian).

7. Khudolii, O.M. (2008). General Fundamentals of Theory and Methodology of Physical Education. Kharkiv: OVS. (in

8. Kirk, D. (2010) Physical Education Futures, London: Routledge. 
9. Kirk, D. (2012) Physical Education Futures: Can we reform physical education in the early 21st Century? eJRIEPS 1$11 p$.

10. Lancaster, S., Teodorescu, R. (2008) Athletic Fitness for Kids. Human Kinetics.

11. Malina, R. M. (2006). Weight training in youth-growth, maturation, and safety: An evidence-based review. Clin J Sport Med, 16, 478-487.

12. McComas A.J. (1998) Skeletal Muscle Form and Function. Human Kinetics: Champaign, IL.

13. Sewall, L., Micheli, L.J. (1986). Strength training for children. J Pediatr Orthop, 6, 143-146.

14. Shuba, L., Chukhlantseva, N., Shuba, V. (2018). Complex development of physical characteristics of 11-12-year-old boys using basketball elements for physical education. Journal of Physical Education and Sport, 18(2), 739-744, 2018. DOI:10.7752/jpes.2018.02108

Bucharest.

15. Thomas, R. (1995). Motor aptitudes. Tests and measurements for young athletes, CCPS Publishing House,

16. Veremeenko, V., Khudolii, O., Ivashchenko, O. (2019). Motor abilities: methods of strength and strength endurance development in middle-school-aged boys in a 4-week physical training cycle. Pedagogics, psychology, medical-biological problems of physical training and sports, 23(2),102-11. https://doi.org/10.15561/18189172.2019.0208

17. William, A. Sands, J.J., Jennifer, K. (2012). Basics of strength and conditioning manual. The National Strength and Conditioning Association's (NSCA).

18. Winnick, J., Short, X. (2014). Brockport Physical Fitness Test Manual (2nd ed). Human Kinetics.

DOI 10.31392/NPU-nc.series15.2021.6(137).05

\author{
Zenina I. \\ Ph.D., Associate Professor of Physical Education \\ Gavrulova N. \\ teacher of the department of physical education \\ Kyzmenko NV \\ senior lecturer at the Department of Physical Education \\ National Technical University of Ukraine Igor Sikorsky Kyiv Polytechnic Institute
}

\title{
FEATURES OF PHYSICAL EDUCATION OF STUDENTS IN THE CONDITIONS OF DISTANCE LEARNING
}

The article reveals the features of physical education of students in terms of distance learning. The main effects of sedentary lifestyle of student youth on their body are revealed. There is a tendency to reduce the motor activity of students, as most of the time students spend on gadgets. Ways and methods of involving student youth in physical exercises in the conditions of distance learning are offered. The role, place and opportunities of distance learning in physical education for students and teachers are determined. The concept of "distance learning technologies" is revealed. Physical education is the only recreational discipline in high school that directly aimed at maintaining the health of the student during the assimilation significant amounts of theoretical material. Reasonably planned motor activity is available the key to gaining strong immunity and disease prevention. In conditions for withdrawal of the discipline "Physical Education" from the curricula of the Free Economic Zone, it is this factor that is often not possible for its quality.

The education system, which has developed over the centuries, has undergone significant modernization in recent years connection with the development and practical use of new information and telecommunication technologies. Traditional communication between teacher and students in lectures, seminars and laboratories classes are largely beginning to be replaced by student-computer communication, teacher-telecommunications system. The above-mentioned changes are most concentrated in the system of distance education. They all note that the formation of personal beliefs regarding the importance of physical activity in human life is a leading factor education of a healthy generation.

Key words: distance learning, physical education, students, physical activity, institutions of higher education.

Зеніна І. В., Гаврилова Н. М., Кузьменко Н. В. Особливості фізичного виховання студентів в умовах дистанційного навчання. В статті розкрито особливості фізичного виховання студентів в умовах дистанційного навчання. Розкрито головні наслідки малорухливого способу життя студентської молоді на їх організм. Виявлено тенденцію зниження рухової активності студентів, оскільки більшу частину свого часу студенти проводять за гаджетами. Запропоновано способи та методи залучення студентської молоді до занять фізичними вправами в умовах дистанційного навчання. Визначено роль, місие та можливості дистанційного навчання з фізичного виховання для студентів і викладачів. Розкрито поняття «дистанційні технології навчання».

Ключові слова: дистаниійне навчання, фрізичне виховання, студенти, рухова активність, заклади вищої освіти.

Formulation of the problem. Distance education in modern realities is becoming remarkable value. Faculties and institutes of distance education are organized. This species educational activities are trying to displace classical education. However, reasonable the combination of all forms of the educational process should provide certain advantages.

The introduction of quarantine in Ukraine has changed the usual forms and methods of teaching academic disciplines. The educational space of the country has moved to distance learning.

Physical education was no exception. In the middle of the school year, teachers and teachers urgently mastered the latest technologies. As never before, acquired relevance of the organization of independent work on physical education. Acquisition and 